\title{
Assessment of the Larvicidal potentials of Thymol derivatives on Anopheles mosquitoes
}

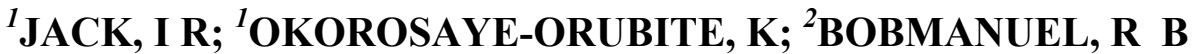 \\ ${ }^{1}$ Department of Chemistry, Rivers State University of Science and Technology, P.M.B. 5080, Port Harcourt, Nigeria \\ ${ }^{2}$ Department of Biology, Rivers State College of Education, P.M.B. 5047 \\ Port Harcourt, Nigeria
}

\begin{abstract}
Thymol (1) a major constituent of the South Eastern Nigeria variety of ocimum gratissimum popularly known as nchawu (scent leaf) was converted to its O-methyl (2), O-ethyl (3), acetate (4) and the Benzyloxy (5) derivatives that are characterized by their spectral data such as infra red, proton n.m.r. and mass spectra. Tests on their insecticidal potency show that, like the parent compound thymol (1), they also possess insecticidal properties in decreasing order Benzyloxy $>$ Acetate $>$ O-ethyl $>$ O-methyl. This order is explained partly by the electron withdrawing tendency of the benzyloxy and acetate groups and also that, as the molecular weight of the derivatives increases the solubility decreases. @JASEM
\end{abstract}

The menace caused by malaria in Nigeria is so devastating that both Government and some organizations have initiated various strategies and programmes for the control of the adult and larvae of the vector (Curtis 1990, Onon 1980 and Matanmi 1991) which causes the disease. In collaboration with the World Health Organization (WHO), Federal Government recently demonstrated a pragmatic approach to the problem of malaria eradication by launching the "roll back malaria."An indigenous plant Ocimum gratissimum of the family labiatae (Hutchinson and Dalziel 1987 and Saunders 1958) has been reported to be rich in geraniol (Charles and Simon 1992) and thymol (Bobmanuel and Jack 2004) and also shown to have antimicrobial, insecticidal and fungicidal properties (Awah 1994 and Ofuya 1990). We have harnessed the structure of thymol and prepared its O-methyl (2), O-ethyl (3), acetate (4) and benzyloxy (5) derivatives scheme 1 with a view to determining their suitability or potentials as insecticides/larvicides.

\section{MATERIALS AND METHODS}

Infra red spectra were recorded on Pye Unicam SP 1050 spectrometer. ${ }^{1} \mathrm{H}$ n.m.r., spectra were obtained from varian HA 100 spectrometer using TMS as an internal standard and chemical shifts are given as $\delta$ (ppm). Mass spectra were taken on an AETMS 9 double focusing spectrometer at $250^{\circ} \mathrm{C}$ and $70 \mathrm{ev}$. All reagents and solvents were purified before use.

Anopheles mosquito larvae were cultured within the main campus of Rivers State College of Education, Rumuolumeni. Five sets of about $2 \mathrm{~kg}$ custard buckets were two-third filled with water and left open outside for about two months. By the time of the experimental set up, thousands of larvae were hatched. The buckets were then covered with fine

*Corresponding author: E-mail mesh sized netted material and kept in the laboratory at room temperature of $30 \pm 2^{\circ} \mathrm{C}$ until use.

An aqueous stock suspension of $25 \mathrm{~g}$ Ocimum gratissimun leaves (also collected on the same campus) in $250 \mathrm{ml}$ water was prepared. Based on previous studies (BobManuel and Jack 2004) 20\% $\mathrm{w} / \mathrm{v}$ of the stock suspension was used which was recorded to effect more than $85 \%$ mortality of larvae three days after treatment. $2 \mathrm{mls}$ each of Thymol methyl ether (2), Ethyl ether (3), acetate (4) and the benzyloxy derivative (5) in $10 \mathrm{ml}$ water were used with $12 \mathrm{ml}$ thymol as control.

10 larvae of the same age were counted into each of 15 petri dishes, each treatment being replicated. The treatments were then introduced into each of the Petri dishes with the larvae. Observations and mortality counts were made one hour after treatment on hourly intervals. The experiment terminated within 3 hours due to optimal mortalities observed.

Preparation of Thymol Derivatives

Thymol O-methyl ether (2): $15 \mathrm{mls}$ ( 0.08 moles) of an ethereal solution of diazomethane was added to a solution of $1 \mathrm{~g}$ ( 0.07 moles) thymol (1) in $4 \mathrm{mls}$ dry tetrahydrofuran (THF) and stirred for 16 hours at room temperature. The solvent was evaporated off and the residue taken up in $60 \mathrm{mls}$ chloroform. This was extracted with $2 \mathrm{~N} \mathrm{NaOH}(20 \mathrm{ml} \times 2)$ and acidified to $\mathrm{pH} 1$ with $3 \mathrm{~N} \mathrm{HCl}$. Re-extraction with chloroform $(15 \mathrm{ml} \times 3)$ and drying over anhydrous $\mathrm{Na}_{2} \mathrm{SO}_{4}$ gave clear oil.

$$
\begin{gathered}
\text { Yield } 0.85 \mathrm{~g}(78 \%) \\
{ }^{1} \mathrm{H} \text { n.m.r. see table } 2 \\
\text { Mass spectrum } \mathrm{M}^{+} 164
\end{gathered}
$$

Thymol O-ethyl ether (3): $500 \mathrm{mg}$ (0.003 moles) of (2) in $30 \mathrm{ml}$ ethanol was treated with ten drops of 
conc. $\mathrm{H}_{2} \mathrm{SO}_{4}$ and the mixture stirred at room temperature. After 2 hours the mixture was poured into $100 \mathrm{ml}$ water and extracted with dichloromethane $(15 \mathrm{ml} \times 3)$, washed with water $(15 \mathrm{ml} \times 2)$ and dried over anhydrous $\mathrm{MgSO}_{4}$. Evaporation of the solvent gave oil.

Yield 450mg (83\%)

${ }^{1}$ H n.m.r. see table 2

Mass spectrum $\mathrm{M}^{+} 178$

Thymol acetate (4): Into a solution of $1.50 \mathrm{~g}(0.01$ moles) thymol (1) in $15 \mathrm{ml}$ pyridine was added $8 \mathrm{ml}$ acetic anhydride and the mixture stirred at room temperature for 6 hours. It was poured into $100 \mathrm{ml}$ ice cold water, allowed to stand for $30 \mathrm{mins}$ and extracted with ethyl acetate $(15 \mathrm{ml} \times 3)$. The ethyl acetate extract was washed with $1 \mathrm{M} \mathrm{HCl}(10 \mathrm{ml} \times 2)$, saturated $\mathrm{NaHCO}_{3}(15 \mathrm{ml}$ x 2) and then with water $(15 \mathrm{ml} \times 2)$. Evaporation of the solvent after drying in anhydrous $\mathrm{Na}_{2} \mathrm{SO}_{4}$ gave an oil.
Yield: $1.60 \mathrm{~g}(84 \%)$

${ }^{1}$ H n.m.r. see table 2

Mass spectrum $\mathrm{M}^{+} 192$

Benzyloxy derivative (5): A solution of $1.20 \mathrm{~g}$ (0.008 moles) thymol in $15 \mathrm{mls}$ dry acetone was stirred under reflux for $8 \mathrm{hrs}$. with a mixture of $2.5 \mathrm{~g}$ ( 0.02 moles $)$ benzyl chloride and $2.8 \mathrm{~g}(0.02$ moles $)$ dry $\mathrm{K}_{2} \mathrm{CO}_{3}$. The mixture was cooled and poured into $20 \mathrm{mls}$ water and extracted with dichloromethane $(20 \mathrm{ml} \times 2)$, washed with water $(15 \mathrm{ml} \times 2)$ and dried over anhydrous $\mathrm{MgSO}_{4}$. Evaporation of the solvent gave yellow oil which was washed with diethyl ether on a short column and obtained as a white gum.

\footnotetext{
Yield 1.40g (73\%)

${ }^{1}$ H n.m.r. see table 2

Mass spectrun $\mathrm{M}^{+} 204$
}

Table 1. Effect of Thymol derivatives on Anopheles mosquito larvae

\begin{tabular}{lccc}
\hline Derivatives & $\begin{array}{l}\text { Mean larvae } \\
\text { tested }\end{array}$ & $\begin{array}{l}\text { Cumulative Mean } \\
\text { Mortality } \pm \text { SE }\end{array}$ & $\begin{array}{l}\text { Cumulative } \\
\text { percent mortality }\end{array}$ \\
\hline Benzyloxy (5) & 10 & $9.8 \pm 3.3$ & 98 \\
Acetate (4) & 10 & $9.1 \pm 2.7$ & 91 \\
Ethyl ether (3) & 10 & $8.8 \pm 2.2$ & 88 \\
Methyl ether (2) & 10 & $8.6 \pm 1.4$ & 86 \\
Thymol (1) & 10 & $8.6 \pm 0.9$ & 86 \\
\hline
\end{tabular}

\section{RESULTS AND DISCUSSIONS}

The results obtained are shown in table 1 . Cumulative mean mortalities for the Benzyloxy (5) and Acetate (4) were significantly different $(\mathrm{P}=0.05)$ compared to the control thymol (1). Cumulative percent mortalities three hours after treatment was also highest for the benzyloxy (98\%) followed by the acetate (91\%). There were no significant differences between the ethyl (3) and methyl (2) ethers in comparison with thymol. The high cumulative mean mortalities and percent mortalities for the benzyloxy and acetate are indicators that they are potential larvicides. This could be attributed partly to decreased solubility of these derivatives as the molecular mass increases. It is a known fact that hydrocarbons are generally insoluble in water hence increasing the molecular mass of thymol means increasing the hydrocarbon content with consequent decrease in solubility. These insoluble thymol derivatives by spreading over the water surface obstruct the breathing of the larvae thereby suffocating them or acting as poison. Also the acetoxy and benzyloxy groups are better electron withdrawing groups than the methyl and ethyl groups which are electron releasing groups.

Scheme 1

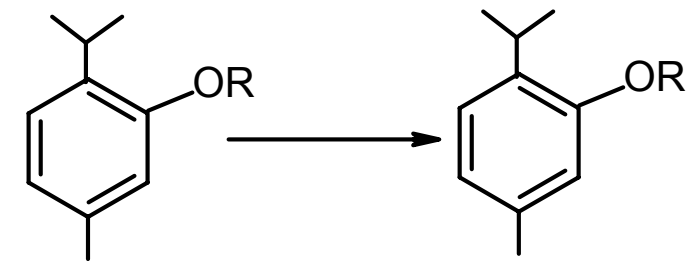

Where : (1) $\mathrm{R}=\mathrm{H}$ Thymol; (2). $\mathrm{R}=\mathrm{CH}_{3}$; (3). $\mathrm{R}=\mathrm{CH}_{2} \mathrm{CH}_{3}$; (4). $\mathrm{R}=\mathrm{OCOCH}_{3}$; (5) $\mathrm{R}=\mathrm{CH}_{2} \mathrm{Ph}$ 
Table 2. Proton magnetic resonance spectra*

\begin{tabular}{|c|c|c|c|c|}
\hline \multirow[t]{3}{*}{ Protons } & \multicolumn{4}{|c|}{ Compounds } \\
\hline & O-methyl & O-ethyl & Acetate (4) & Benzyloxy (5) \\
\hline & Ether (2) & Ether (3) & & \\
\hline $\mathrm{H}-8$ & & & & \\
\hline $\mathrm{H}-9 \mathrm{~J}$ & $1.18 \mathrm{~d}(8)$ & $1.14 \mathrm{~d}(8)$ & $1.19 \mathrm{~d}(8)$ & $1.20 \mathrm{~d}(8)$ \\
\hline $\mathrm{H}-10$ & $2.19 \mathrm{~s}$ & $2.18 \mathrm{~s}$ & $2.20 \mathrm{~s}$ & $2.17 \mathrm{~s}$ \\
\hline $\mathrm{H}-7$ & $3.16 \mathrm{dq}(7.5)$ & $3.18 \mathrm{dq}(8)$ & $3.17 \mathrm{dq}(8)$ & $3.16 \mathrm{dq}(7.5)$ \\
\hline $\mathrm{OCH}_{3}$ & $3.70 \mathrm{~s}$ & - & - & - \\
\hline $\mathrm{OC} \underline{\bar{H}}_{2} \mathrm{CH}_{3}$ & - & $3.40 \mathrm{q}(7)$ & - & - \\
\hline $\mathrm{OC}_{2} \mathrm{CH}_{3}$ & - & $1.24 \mathrm{t}(7)$ & - & - \\
\hline $\mathrm{OCO} \mathrm{C} \underline{\mathrm{H}}_{3}$ & - & - & $2.23 \mathrm{~s}$ & - \\
\hline $\mathrm{OCH}_{2} \mathrm{Ph}$ & - & - & - & $5.05 \mathrm{~s}$ \\
\hline $\mathrm{ArH}$ & $6.51-7.07 \mathrm{~m}$ & $6.40-6.95 m$ & $6.35-6.80 m$ & $\begin{array}{l}6.49-7.10 \mathrm{~m} \\
7.20-7.45 \mathrm{~m}\end{array}$ \\
\hline
\end{tabular}

* Spectra run in $\mathrm{CDCl}_{3}$

\section{REFERENCES}

Awah, R. T. (1994) In vivo use of extracts from ocimum gratissimum against Phytophthora palmivora causing blackpod diseases of cocoa. Annals of Applied Biology 173-178

BobManuel, R. B. and Jack, I. R. (2004) Evaluation of the larvicidal potential of Ocimum gratissimum on mosquitoes Int. J. Sci. Tech. 3 Vol.2 28-29

Charles, D. J. and Simon, J. E. (1992) A new geraniol chemotype of ocimum gratissimum L. J. of Essential oil Research 4:3, 231-234

Curtis, C. F. (1990) Pyrethroid impregnation of beds, nets and curtains against malarial mosquitoes pesticides. Outlook Pub. London pp 8-10
Hutchinson, J. and Dalziel, J. M. (1987) Plants of the Labiatae family in Flora of West Tropical Africa, $2^{\text {nd }}$ ed. Pt. $1 \& 2$ Vol. 2451

Matanmi, B. A. (1991) Microbial insecticides of Nigeria: State of the art. Nig. J. of Entomology, 23-34, 101-102

Ofuya, T. I. (1990) Oviposition deterrence and ovicidal properties of some plant powders against collosobruchus maculates in stored cowpea seeds. J. of Agric. Science 115, 3, 343 $-345$

Onon, R. H. (1980) Introduction to parasitology (Ed. Hodd and Stronghton Ltd. London) $\quad 9-21$

Saunders, H. N. (1958) A handbook of West African flowers (Ed. Oxford Univ. Press) pp 4 